\title{
HUBUNGAN STRES TERHADAP PROSES ADAPTASI (TEORI CALLISTA ROY) PADA LANJUT USIA DENGAN HIPERTENSI DI WILAYAH KERJA PUSKESMAS PERUMNAS II PONTIANAK
}

\author{
THE RELATIONSHIP BETWEEN STRESS ADAPTATION PROCESS \\ (THEORY OF CALLISTA ROY) IN THE ELDERLY WITH \\ HYPERTENSION IN THE WORKING AREA \\ CLINICS PERUMNAS II OF PONTIANAK
}

\author{
Ulfa Muzliyati*, Parliani**, Yoga Pramana*** \\ *Mahasiswa Program Studi Keperawatan Fakultas Kedokteran Universitas Tanjungpura, \\ Email: ulfamuzliyati@gmail.com \\ **Dosen Program Studi Keperawatan Sekolah Tinggi Ilmu Keperawatan Muhammadiyah Pontianak \\ ***Dosen Program Studi Keperawatan Fakultas Kedokteran Universitas Tanjungpura
}

\begin{abstract}
ABSTRAK
Latar Belakang: Stres merupakan suatu reaksi alami tubuh untuk mempertahankan diri dari stressor. Stressor dapat menghasilkan respon koping adaptif maupun maladaptif tubuh yang dapat menyebabkan hipertensi. Proses adaptasi merupakan suatu cara yang dapat berpengaruh terhadap perilaku penderita dalam memanajemen stres sehingga terhindar dari hipertensi.

Tujuan: Untuk mengetahui hubungan antara stres terhadap proses adaptasi dalam teori Callista Roy pada lanjut usia yang menderita hipertensi di wilayah kerja Puskesmas Perumnas II Pontianak.

Metode : Penelitian ini merupakan penelitian kuantitatif dengan desain analitik korelatif dan menggunakan pendekatan cross sectional. Sampel dalam penelitian ini berjumlah 79 orang dengan teknik pengambilan sampling yaitu convinience sampling. Hasil penelitian dianalisa menggunakan uji Chi Square.

Hasil : Hasil menunjukkan nilai Sig $(2$-tailed $)=0,001(a<0,05)$, hal ini menunjukkan bahwa ada hubungan antara tingkat stres terhadap tingkat proses adaptasi koping pada lanjut usia yang menderita hipertensi

Kesimpulan : Ada hubungan antara tingkat stres terhadap tingkat proses adaptasi koping pada lansia dengan hipertensi di Wilayah Kerja Puskesmas Perumnas II Pontianak . Hubungan antara tingkat stres terhadap tingkat proses adaptasi koping pada lansia dapat menjadi acuan bagi penderita hipertensi untuk mencegah hipertensi dengan manajemen stres dan adaptasi koping.
\end{abstract}

Kata Kunci : Stres, Proses Adaptasi, Lansia, Hipertensi, Teori Callista Roy

Referensi : 68 (2008-2018) 


\begin{abstract}
Background: stress is a natural reaction of the body to defend itself from the stressor. Stressor can produce response Adaptive koping or maladaptif body which can lead to hypertension. The process of adaptation is a way that can affect the behavior of the sufferers in create stress so that spared from hypertension.

Objective: to know the relationship between the stress process of adaptation in the theory of Callista Roy on the elderly who suffer from hypertension in working area Clinics Perumnas II of Pontianak.

Methods: this research is quantitative research. The design of the study was analytic with cross sectional approach correlative. The sample in this study amounted to 79 people with sampling-taking techniques i.e. convinience sampling. Results of the study were analyzed using Chi Square..

Results: the results show the value of the Sig (2-tailed) $=0.001(a<0.05)$, this indicates that there is a relationship between stress level against the process level adaptation koping on seniors who suffer from hypertension

Conclusion: there is a relationship between stress level against the process level adaptation koping on the elderly with hypertension in the working area Clinics Perumnas II of Pontianak. The relationship between stress level against the process level adaptation koping on the elderly can be a reference for people with hypertension to prevent hypertension with stress management and adaptation koping.
\end{abstract}

Key Words: Stress, The Process Of Adaptation, The Elderly, Hypertension, Theories Of Callista Roy Reference: 68 (2008-2018) 


\section{PENDAHULUAN}

Stres merupakan suatu reaksi dari tubuh untuk mempertahankan diri terhadap stressor. ${ }^{1}$ Stressor merupakan suatu keadaan yang menimbulkan stres. ${ }^{2}$ Stressor dapat menghasilkan respon koping adaptif maupun maladaptif tubuh terhadap stresor yang menyebabkan perubahan pada fungsi normal tubuh yang akan terus menerus memicu respon seseorang sehingga dapat meningkatkan tekanan darah secara kronis, kambuhnya hipertensi sampai menurunnya keefektifan kekebalan tubuh. ${ }^{3}$

Stres dapat memicu timbulnya hipertensi melalui aktivasi sistem saraf simpatis yang mengakibatkan naiknya tekanan darah secara tidak menentu. ${ }^{4}$ Pada saat seseorang mengalami stres, hormon adrenalin akan dilepaskan dan kemudian akan meningkatkan tekanan darah melalui kontraksi arteri (vasokontriksi) dan dapat meningkatan denyut jantung. ${ }^{5}$ Apabila stres berlanjut, tekanan darah akan tetap tinggi sehingga orang tersebut akan mengalami hipertensi. ${ }^{4}$

World Health Organitation (WHO) 2015 menyebutkan stres menjadi salah satu faktor utama dalam peningkatan tekanan darah, hal serupa juga diungkapkan oleh hasil penelitian Madhumita tahun 2014 yang menemukan bahwa stres memiliki hubungan yang paling tinggi dalam peningkatan tekanan darah dibandingkan dengan usia, jenis kelamin dan kondisi sosio demografi penderita. $^{6,7}$ Penelitian diatas menunjukkan bahwa stres menjadi faktor yang paling berpengaruh dalam meningkatkan tekanan darah. Stres perlu diwaspadai oleh setiap orang terutama lanjut usia sebagai individu yang rentan akan penyakit dan sebagai kelompok umur yang paling banyak menderita hipertensi. ${ }^{8}$

Hipertensi atau disebut juga tekanan darah tinggi adalah suatu keadaan seseorang mengalami peningkatan tekanan darah di atas normal pada pemeriksaan tekanan darah. ${ }^{9}$ Seiring dengan pertambahan usia seseorang, insiden hipertensi juga meningkat. Peningkatan usia pada seseorang dapat menyebabkan beberapa perubahan fisiologis seperti peningkatan aktivitas simpatik dan resistensi perifer yang terjadi khususnya pada lansia. Setelah usia 45-55 tahun, terjadi penebalan dinding arteri oleh zat kolagen pada lapisan otot akan menyebabkan penyempitan sehingga tekanan darah menjadi meningkat. ${ }^{9}$

Menurut data WHO, prevelensi hipertensi di seluruh dunia terdapat sekitar 972 juta orang atau $26,4 \%$ orang yang mengidap hipertensi, angka ini kemungkinan akan meningkat menjadi $29,2 \%$ di tahun 2025. Didapatkan data dari 972 juta penderita hipertensi, terdapat 333 juta berada di negara maju dan 639 sisanya berada di negara berkembang, termasuk Indonesia. ${ }^{10}$ Di Indonesia hipertensi masih merupakan tantangan besar dengan prevalensi yang cukup tinggi, yaitu sebesar $32,4 \%$ dan semakin meningkat seiring dengan pertambahan usia. ${ }^{11}$ Berdasarkan Riset Kesehatan Dasar tahun 2013, prevalensi terjadinya hipertensi berdasarkan usia didapatkan $36,2 \%$ pada usia $<40$ tahun, dan $63,8 \%$ pada usia $\geq 60$ tahun yang berarti bahwa hipertensi banyak terjadi pada lanjut usia. $^{12,13}$

Kalimantan Barat merupakan salah satu provinsi di Indonesia yang memiliki prevalensi hipertensi yang cukup tinggi. Berdasarkan hasil studi pendahuluan di Dinas Kesehatan Provinsi Kalimantan Barat, jumlah penderita hipertensi pada tahun 2017 tercatat sebesar 26.946 penderita. Berdasarkan data yang diperoleh dari Dinas Kesehatan Kota Pontianak pada tahun 2017, kasus hipertensi tercatat sebanyak 10.763 jiwa, dengan jumlah kunjungan tertinggi berada di Puskesmas Perumnas II Pontianak. Berdasarkan data yang diperoleh dari Puskesmas Perumnas II Pontianak pada tahun 2017 terdapat 2.860 kunjungan penyakit hipertensi, dimana terdapat 1.494 kunjungan lansia yang menderita hipertensi. Pada tahun 2018 tercatat jumlah penderita hipertensi pada lansia dari bulan januarimaret sebanyak 373 kunjungan. 
Hipertensi menjadi masalah pada usia lanjut karena sering ditemukan menjadi faktor utama payah jantung dan penyakit koroner. Masyarakat sering menganggap hipertensi pada usia lanjut adalah hal yang biasa, tidak perlu diobati karena merupakan hal yang wajar. Masyarakat tidak menaruh perhatian terhadap penyakit hipertensi yang diangap sepele, tanpa menyadari bahwa penyakit ini menjadi berbahaya dan menyebabkan berbagai kelainan yang lebih fatal. Tekanan darah yang selalu tinggi bisa menyebabkan komplikasi yaitu penyakit jantung koroner, infark jantung, stroke dan gagal ginjal. ${ }^{14}$ Pada waktu seseorang memasuki masa usia lanjut, terjadi berbagai perubahan baik yang bersifat fisik, mental, maupun sosial. Salah satu masalah yang sering dialami lansia adalah stres. Stres dapat meningkatkan tekanan darah secara intermiten, apabila stres berlangsung lama dapat mengakibatkan terjadinya hipertensi. Stres yang terlalu besar dapat memicu terjadinya berbagai penyakit, misalnya sakit kepala, sulit tidur, hipertensi, penyakit jantung, dan stroke. ${ }^{15}$

Berdasarkan hasil studi pendahuluan yang dilakukan oleh peneliti pada bulan april, terdapat 10 lansia yang mengalami hipertensi diberikan skrining tanda dan gejala stres, didapatkan bahwa terdapat $60 \%$ lansia yang mengalami stres. Hal ini menunjukkan bahwa salah satu faktor yang menyebabkan lansia mengalami hipertensi adalah stres. Berdasarkan hasil wawancara, lansia juga mengatakan bahwa merasa sakit kepala ketika sedang mengalami beban fikiran yang berat. Sakit kepala merupakan salah satu tanda dan gejala umum yang lansia rasakan, terutama ketika lansia sedang mengalami suatu masalah. Hasil studi pendahuluan ini didukung juga oleh penelitian yang dilkukan oleh Islami (2015), yang menyatakan bahwa banyak penderita hipertensi yang datang untuk melakukan pemeriksaan di puskesmas tersebut yang mengeluhkan adanya tekanan atau tuntutan pada diri mereka, seperti misalnya adanya tuntutan pekerjaan, tuntutan ekonomi, dan sebagainya yang membuat mereka mengalami stres. 5

Stres dapat diatasi dengan adanya adaptasi koping yang adaptif sehingga mampu beradaptasi dengan faktor-faktor yang menimbulkan stres/stressor. Adaptasi koping merupakan respon pertahanan individu terhadap suatu masalah, apakah berespon positif ataupun maladaptif. Perawat memberikan pelayanan kesehatan melalui upaya rehabilitatif serta melaksanakan asuhan keperawatan baik itu secara individu, keluarga, kelompok dan masyarakat. Dalam hal ini aplikasi teori keperawatan sangat dibutuhkan untuk dapat menggambarkan proses adaptasi lansia terhadap stres pada penderita hipertensi, salah satu teori keperawatan yang dapat menggambarkan masalah diatas adalah teori adaptasi Callista Roy. Teori Callista Roy menjelaskan tentang bagaimana individu mampu meningkatkan kesehatan dengan cara mempertahankan perilaku adaptif dan mengubah perilaku maladaptif. Teori tersebut menekankan pada kemampuan penderita hipertensi untuk beradaptasi dalam mengatasi stressor agar terhindar dari hipertensi. ${ }^{16}$

Berdasarkan latar belakang dan fenomena yang ada, peneliti tertarik untuk mengetahui lebih dalam mengenai hubungan antara stres terhadap proses adaptasi dalam teori Callista Roy pada lanjut usia dengan hipertensi di wilayah kerja Puskesmas Perumnas II Pontianak.

\section{METODE}

Penelitian ini adalah penelitian Kuantitatif yang menggunakan desain Analitik Korelasi untuk melihat hubungan antara variabel stres dengan variabel proses adaptasi dengan menggunakan pendekatan Cross Sectional. ${ }^{18}$

Populasi pada penelitian ini adalah semua lansia yang mengalami hipertensi di wilayah kerja Puskesmas Perumnas II Pontianak dengan jumlah populasi sebanyak 373 lansia yang mengalami hipertensi. Sampel penelitian ini adalah lansia di wilayah kerja Puskesmas Perumnas II Pontianak yang bersedia menjadi responden. 
Teknik pengambilan sampel yang digunakan ialah Convinience sampling. Peneliti mengambil sampel sesuai dengan kriteria inklusi dan ekslusi berjumlah 79 orang.

Kriteria inklusi dalam penelitian ini yaitu: lansia yang berusia $\geq 60$ Tahun, lansia dengan tekanan darah sistolik 140-180 $\mathrm{mmHg}$ dan diastolik 90-110 $\mathrm{mmHg}$, lansia dengan hipertensi minimal 5 tahun, lansia dengan kondisi hemodinamik stabil. Sedangkan kriteria ekslusi yaitu : lansia yang mengalami dimensia dan lansia yang tidak setuju menjadi responden.

Variabel independen dalam penelitian ini adalah stres sedangkan variabel dependennya adalah proses adaptasi pada lansia dengan hipertensi .

Tempat penelitian dilakukan di Wilayah Kerja Puskesmas Perumnas II Pontianak. Penelitian ini dimulai pada bulan Juli 2018.

Instrumen yang digunakan dalam penelitian ini adalah alat Sphygmomanometer air raksa dan stetoskop yang sudah dikalibrasi alat, lembar kuesioner terstruktur yaitu kuesioner Percieved Stres Scale (PSS) dan kuesioner Coping Adaptation Processing Scale (CAPS).

\section{HASIL PENELITIAN}

\section{Karakteristik Responden}

Tabel 4.1 Distribusi Karakteristik Demografi Responden Berdasarkan Jenis Kelamin, Usia, Tingkat Pendidikan, Tingkat Hipertensi dan Tingkat Stres di Wilayah Kerja Puskesmas Perumnas II Pontianak $(\mathrm{n}=79)$

\begin{tabular}{ccc}
\hline \multirow{2}{*}{ Karakteristik } & \multicolumn{3}{c}{ Jumlah } \\
\cline { 2 - 3 } & Frekuensi (f) & Persentase (\%) \\
\hline Jenis Kelamin & 35 & 44,3 \\
Laki-Laki & 44 & 55,7
\end{tabular}

Usia

$\begin{array}{ccc}60-74 \text { tahun } & 75 & 94,9 \\ 75-90 \text { tahun } & 4 & 5,1\end{array}$

Tingkat Pendidikan

$\begin{array}{ccc}\text { Tidak Sekolah } & 6 & 7,6 \\ \text { SD/Sederajat } & 28 & 35,4 \\ \text { SMP?Sederajat } & 15 & 19,0 \\ \text { SMA/Sederajat } & 30 & 38,0 \\ & & \\ \text { Hipertensi } & & 30,4 \\ \text { Ringan } & 24 & 69,6 \\ \text { Sedang } & 25 & \end{array}$

Tingkat Hipertensi

Sumber : Data Primer (2018)

Berdasarkan tabel 4.1 didapatkan bahwa distribusi karakteristik demografi responden berdasarkan jenis kelamin sebagian besar adalah perempuan sebanyak 44 responden $(55,7 \%)$, sedangkan laki-laki 35 responden $(44,3 \%)$. Berdasarkan usia hampir seluruhnya berada pada rentang usia 60-74 tahun yaitu sebanyak 75 responden $(94,9 \%)$, kemudian usia 75-90 tahun yaitu 4 responden $(5,1 \%)$. Berdasarkan tingkat pendidikan hampir dari setengahnya memiliki tingkat pendidikan SMA /Sederajat yaitu sebanyak 30 responden $(38,0 \%)$, kemudian SD/Sederajat yaitu 28 responden $(35,4 \%)$, SMP/Sederajat yaitu 15 responden $(19,0 \%)$, dan Tidak Sekolah yaitu 6 responden $(7,6 \%)$. Tingkat hipertensi sebagian besar berada pada kategori hipertensi sedang yaitu sebanyak 55 
responden $(69,6 \%)$ dan kategori hipertensi

ringan yaitu 24 responden $(30,4 \%)$.

Analisa Uniariat

Tabel 4.5 Distribusi Responden Berdasarkan Tingkat Stres di Wilayah Kerja Puskesmas Perumnas II Pontianak $(\mathrm{n}=79)$

\begin{tabular}{cccc}
\hline \multirow{2}{*}{ Tingkat Stres } & \multicolumn{3}{c}{ Jumlah } \\
\cline { 3 - 4 } & Ringan & Frekuensi (f) & Persentase (\%) \\
\hline Sedang & 3 & 3,8 \\
& Berat & 63 & 79,7 \\
& Total & 13 & 16,5 \\
\hline Sumber & & 79 & 100 \\
\hline
\end{tabular}

Berdasarkan tabel 4.5 didapatkan sebanyak 13 responden $(16,5 \%)$, dan ingkat bahwa distribusi tingkat stres responden stres ringan yaitu sebanyak 3 responden dapat dilihat hampir seluruhnya memiliki $(3,8 \%)$. tingkat stres sedang yaitu sebanyak 63 responden $(79,7 \%)$, tingkat stres berat yaitu

Tabel 4.6 Distribusi Responden Berdasarkan Tingkat Proses Adaptasi Koping di Wilayah Kerja Puskesmas Perumnas II Pontianak $(\mathrm{n}=79)$

\begin{tabular}{cccc}
\hline \multirow{2}{*}{ Tingkat Proses Adaptasi Koping } & \multicolumn{3}{c}{ Jumlah } \\
\cline { 3 - 4 } & Tinggi & Frekuensi (f) & Persentase (\%) \\
\hline Rendah & 39 & 49,4 \\
& Total & 40 & 50,6 \\
\hline Sumber & & 79 & Primer
\end{tabular}

Berdasarkan tabel 4.6 didapatkan koping pada kategori rendah yaitu sebanyak bahwa distribusi tingkat proses adaptasi 40 responden $(50,6 \%)$, memiliki tingkat koping responden dapat dilihat sebagian proses adaptasi koping pada kategori tinggi besar memiliki tingkat proses adaptasi yaitu sebanyak 39 responden $(49,4 \%)$

\section{Analisa Bivariat}

Tabel 4.7 Distribusi Responden Berdasarkan Hubungan Tingkat Stres Terhadap Tingkat Proses Adaptasi Koping Responden Di Wilayah Kerja Puskesmas Perumnas II Pontianak (N = 79)

\begin{tabular}{|c|c|c|c|c|c|c|c|}
\hline \multirow{3}{*}{ Tingkat Stres } & \multicolumn{4}{|c|}{ Tingkat Proses Adaptasi } & \multirow{2}{*}{\multicolumn{2}{|c|}{ Total }} & \multirow{2}{*}{ Nilai $p$} \\
\hline & \multicolumn{2}{|c|}{ Tinggi } & \multicolumn{2}{|c|}{ Rendah } & & & \\
\hline & (f) & $(\%)$ & (f) & $(\%)$ & (f) & $(\%)$ & \multirow{5}{*}{$\begin{array}{l}P \text { Value } \\
=0,001\end{array}$} \\
\hline Ringan & 3 & 100 & 0 & 0 & 3 & 100 & \\
\hline Sedang & 36 & 57,1 & 27 & 42,9 & 63 & 100 & \\
\hline Tinggi & 0 & 0 & 13 & 100 & 13 & 100 & \\
\hline Total & 39 & 157,1 & 40 & 142,9 & 79 & 300 & \\
\hline
\end{tabular}

Berdasarkan tabel 4.7 menunjukkan stres ringan dengan proses adaptasi yang bahwa proporsi responden yang memiliki rendah. Sedangkan responden yang memiliki tingkat stres ringan seluruhnya memiliki tingkat proses adaptasi yang tinggi yaitu tingkat stres sedang sebagian besar memiliki tingkat proses adaptasi yang tinggi yaitu sebanyak 3 responden (100\%), kemudian tidak ada responden yang memiliki tingkat sebanyak 36 responden $(57,1 \%)$ dan responden yang memiliki tingkat stres 
sedang hampir dari setengahnya memiliki tingkat proses adaptasi yang rendah yaitu sebanyak 27 responden (42,9\%). Sedangkan responden yang memiliki tingkat stres tinggi seluruhnya memiliki tingkat proses adaptasi yang rendah yaitu sebanyak 13 responden (100\%) dan tidak ada responden yang memiliki tingkat stres tinggi yang memiliki tingkat proses adaptasi yang tinggi.

Uji Chi-Square dilakukan terhadap data untuk mencari hubungan antara variabel bebas yaitu tingkat stres dengan variabel terikat yaitu tingkat proses adaptasi koping. Pada Uji Chi Square didapatkan sel yang nilai expectednya kurang dari lima ada sebanyak 2 sel $(33,3 \%)$ sehingga saya menggunakan alternatif penggabungan cell. Hasil Uji Chi Square dengan penggabungan cell menunjukkan nilai Sig (2-tailed) $=0,001$ $(a<0,05)$, secara statistik dapat disimpulkan ada hubungan antara tingkat stres terhadap tingkat proses adaptasi koping lansia dengan hipertensi di Wilayah Kerja Puskesmas Perumnas II Pontianak.

\section{PEMBAHASAN}

Pada penelitian ini menunjukkan bahwa stres dengan hipertensi lebih sering terjadi pada perempuan dari pada laki-laki dengan jumlah perempuan lebih banyak yaitu sebanyak 44 responden $(55,7 \%)$ sedangkan jumlah laki-laki yaitu 35 responden $(44,3 \%)$. Penelitian ini sejalan dengan penelitian yang dilakukan oleh Mardiana (2014) yang menunjukkan bahwa jenis kelamin responden sebagian besar yaitu perempuan dengan jumlah 33 responden (55\%), sedangkan laki-laki berjumlah 27 responden $(45 \%) .{ }^{19}$ Pada penelitian ini didapatkan lebih banyak jumlah perempuan yang mengalami hipertensi hal ini didapatkan karena jumlah responden yang berkunjung ke Puskesmas Perumnas II lebih banyak perempuan daripada laki-laki. Faktor lainnya yang menyebabkan lebih banyak lansia perempuan yang mengalami stres karena banyaknya lansia perempuan yang sudah tidak produktif lagi dan banyaknya lansia perempuan sudah ditinggal pasangannya.

Penelitian ini menunjukkan bahwa usia responden hampir seluruhnya berada pada rentang usia 60-74 tahun yaitu sebanyak 75 responden $(94,9 \%)$, sedangkan responden yang berada pada rentang usia 74-90 tahun yaitu sebanyak 4 responden $(5,1 \%)$. Penelitian ini sejalan dengan penelitian yang dilakukan oleh Mardiana (2014) yang menunjukkan bahwa responden terbanyak pada umur 60-74 tahun dengan jumlah 43 orang $(71,7 \%) .{ }^{19}$ Berdasarkan hasil penelitian banyaknya lansia yang mengalami hipertensi di wilayah kerja Puskesmas Perumnas II yang paling banyak adalah berumur $60-74$ tahun hal tersebut disebabkan dikarenakan sedikitnya jumlah responden yang berusia 75-90 tahun. Hasil penelitian ini didapatkan semakin bertambahnya umur semakin sulit lansia dalam memanajemen stresnya, berdasarkan wawancara yang dilakukan oleh peneliti, lansia mengatakan bahwa tingginya tekanan yang dirasakan atau dialami oleh lansia sebagai akibat dari stresor berupa perubahan-perubahan baik fisik, mental, maupun sosial dalam kehidupan yang dialami lansia.

Pada penelitian ini menunjukkan bahwa responden terbanyak pada tingkat pendidikan adalah tingkat pendidikan SMA /Sederajat yaitu sebanyak 30 responden $(38,0 \%)$, kemudian SD/Sederajat yaitu 28 responden $(35,4 \%), \mathrm{SMP} /$ Sederajat yaitu 15 responden $(19,0 \%)$, dan Tidak Sekolah yaitu 6 responden $(7,6 \%)$. Hasil pada penelitian ini sejalan dengan penelitian yang dilakukan oleh Mardiana (2014) yang menunjukkan bahwa responden berdasarkan pendidikan terbanyak yaitu SMA dengan frekuensi sebanyak 26 orang $(43,3 \%) .{ }^{19}$ Berdasarkan hasil penelitian didapatkan banyaknya lansia yang tingkat pendidikan yang paling banyak mengalami stres dengan hipertensi adalah tingkat pendidikan SMA, hal ini disebabkan karena pada penelitian ini tidak didapatkan responden yang berpendidikan sampai ke jenjang yang lebih tinggi seperti perguruan tinggi, karena pada saat lansia duduk dibangku sekolah, lansia dengan tingkat 
SMA sudah bisa langsung bekerja dan SMA sudah dikatakan pendidikan yang sangat tinggi.

Penelitian ini menunjukkan bahwa kategori hipertensi responden paling banyak berada pada kategori sedang yaitu sebanyak 55 responden $(69,6 \%)$, sedngkan untuk kategori hipertensi ringan yaitu sebanyak 24 responden $(30,4 \%)$. Hasil penelitian ini sejalan dengan penelitian yang dilakukan oleh Mardiana (2014) yang menunjukkan bahwa lansia yang terkena hipertensi lebih banyak pada hipertensi tingkat sedang yaitu sebanyak 31 responden $(51,7 \%)$, kemudian hipertensi ringan sebanyak 17 responden $(28,3 \%){ }^{19}$ Berdasarkan hasil penelitian, banyaknya lansia yang mengalami hipertensi sedang karena karena pada umumnya semakin bertambahnya umur mengakibatkan tekanan darah semakin meningkat, sedangkan pada penelitian ini tingkat hipertensi yang didapat adalah tingkat hipertensi sedang dikarenakan peneliti tidak memasukkan tingkat hipertensi berat untuk menjadi responden.

Pada penelitian ini menunjukkan bahwa responden hampir seluruhnya memiliki tingkat stres sedang yaitu sebanyak 63 responden $(79,7 \%)$, tingkat stres berat yaitu sebanyak 13 responden $(16,5 \%)$, dan tingkat stres ringan yaitu sebanyak 3 responden $(3,8 \%)$. Penelitian ini sejalan dengan penelitian yang dilakukan oleh Mardiana (2014) yang menunjukkan bahwa tingkat stres pada lansia yang terbanyak pada kategori tingkat stres sedang dengan jumlah 51 responden $(85 \%) .{ }^{19}$ Berdasarkan hasil penelitian ini didapatkan bahwa banyak lansia yang mengalami stres sedang. Hal tersebut didapatkan dari hasil pengisian kuesioner responden di wilayah kerja Puskesmas Perumnas II Pontianak, didapatkan bahwa lansia menyatakan sulitnya lansia dalam mengontrol marah, sering merasa gelisah, merasa tidak mampu mengatasi masalah pribadi, merasa tidak berdaya dalam menyelesaikan pekerjaan, dan mudah tersinggung. Stes yang dialami lansia disebabkan karena adanya stressor, stressor ini dapat terjadi karena adanya masalah yang harus didapi oleh lansia baik secara fisik ataupun secara psikis.

Pada penelitian ini menunjukkan bahwa responden paling banyak memiliki tingkat proses adaptasi koping pada kategori rendah yaitu sebanyak 40 responden $(50,6 \%)$, memiliki tingkat proses adaptasi koping pada kategori tinggi yaitu sebanyak 39 responden $(49,4 \%)$. Hasil pada penelitian ini tidak sejalan dengan penelitian yang dilakukan oleh Yuliani (2013), yang menunjukkan bahwa 30 responden lansia yang menderita hipertensi di Wilayah Kerja Puskesmas Wonopringgo Kabupaten Pekalongan, 16 responden $(53,3 \%)$ mempunyai mekanisme koping adaptif. Hal ini menunjukkan bahwa sebagian besar responden lansia yang menderita hipertensi di Wilayah Kerja Puskesmas Wonopringgo Kabupaten Pekalongan mempunyai mekanisme koping adaptif (baik). ${ }^{20}$ Berdasarkan hasil penelitian ini didapatkan lebih banyaknya lansia yang memiliki adaptasi koping yang rendah karena banyaknya lansia yang tidak dapat memanajemen kopingnya dalam mengatasi masalah. Hal tersebut didapatkan dari hasil pengisian kuesioner yang diisi oleh lansia. Lansia menyatakan bahwa sulit mengikuti banyak petunjuk dalam waktu bersamaan ketika ada masalah. Berdasarakan hasil wawancara hal ini disebabkan karena sulitnya lansia dalam memanajemen kopingnya dalam mengatasi masalah.

Hasil analisis statistik dengan menggunakan Uji Chi Square diperoleh nilai Sig $(2$-tailed $)=0,001(a<0,05)$, secara statistik dapat disimpulkan ada hubungan antara tingkat stres terhadap tingkat proses adaptasi koping pada responden di Wilayah Kerja Puskesmas Perumnas II Pontianak. Hasil penelitian ini sejalan dengan penelitian yang dilakukan oleh Rahmat (2012) yang menyatakan bahwa terdapat hubungan signifikan antara tingkat stres dengan mekanisme koping pada lansia hipertensi. ${ }^{21}$ Tingkat pengetahuan dan intelegensi, kekuatan ego, kepercayaan atau religi serta filosofi yang dianut, akan mempengaruhi kemampuan koping untuk mengurangi stres. 
Berdasarkan penelitian, stres yang dialami responden sebagian besar disebabkan karena sulitnya lansia dalam mengontrol marah. Koping yang dilakukan responden dalam mengatasi stres antara lain dengan berbicara masalahnya kepada keluarga/orang terdekat, melakukan hal yang disenanginya dan juga melakukan pendekatan spiritual.

\section{IMPLIKASI KEPERAWATAN}

Penelitian ini dapat dijadikan sebagai dasar bagi perawat untuk meningkatkan asuhan keperawatan. Penting bagi perawat memiliki kemampuan untuk mengaplikasikan asuhan keperawatan secara komprehensif. Dari hasil penelitian yang didapatkan, dapat dijadikan data bagi Puskesmas Perumnas II Pontianak untuk membuat strategi-strategi baru dalam pelayanan kesehatan mengenai pencegahan hipertensi yang disebabkan oleh stres. Perawat dapat melaksanakan penyuluhan kesehatan mengenai pencegahan hipertensi yang disebabkan oleh stres dan pentingnya adaptasi koping terhadap stres dan membagikan brosur/leaflet sehingga dapat membantu untuk penanggulangan dan pencegahan stres yang dapat menyebabkan hipertensi.

\section{KESIMPULAN}

Berdasarkan hasil penelitian secara umum dapat disimpulkan bahwa ada hubungan antara tingkat stres terhadap tingkat proses adaptasi koping pada responden di Wilayah Kerja Puskesmas Perumnas II Pontianak dan secara khusus dapat disimpulkan sebagai berikut : berdasarkan karakteristik responden di Wilayah Kerja Puskesmas Perumnas II Pontianak didapatkan jenis kelamin sebagian besar adalah perempuan, usia hampir seluruhnya adalah pada rentang usia 60-74 tahun, tingkat pendidikan terbanyak adalah SMA/Sederajat, dan kategori hipertensi responden sebagian besar berada pada kategori sedang. Tingkat stres responden pada lansia yang menderita Hipertensi di Wilayah Kerja Puskesmas Perumnas II Pontianak hampir seluruhnya memiliki tingkat stres sedang. Hal tersebut didapatkan dari hasil pengisian kuesioner responden, didapatkan bahwa banyak lansia menyatakan sulitnya lansia dalam mengontrol marah, sering merasa gelisah, merasa tidak mampu mengatasi masalah pribadi, merasa tidak berdaya dalam menyelesaikan pekerjaan, dan mudah tersinggung. Tingkat proses adaptasi koping di Wilayah Kerja Puskesmas Perumnas II Pontianak sebagian besar berada pada kategori rendah. Berdasarkan hasil penelitian ini didapatkan lebih banyaknya lansia yang memiliki adaptasi koping yang rendah karena banyaknya lansia yang tidak dapat memanajemen kopingnya dalam mengatasi masalah. Ada hubungan antara tingkat stres terhadap tingkat proses adaptasi koping pada responden di Wilayah Kerja Puskesmas Perumnas II Pontianak dengan nilai Sig $(2$-tailed $)=0,001(a<0,05)$. Hal ini berarti H0 di tolak pada hubungan antara tingkat stres terhadap tingkat proses adaptasi koping pada responden di Wilayah Kerja Puskesmas Perumnas II Pontianak

\section{SARAN}

Saran dalam penelitian ini diharapkan dapat meningkatkan upaya konseling, informasi dan edukasi kepada pasien mengenai pencegahan hipertensi bagi puskesmas, dengan cara melakukan manajemen adaptasi koping untuk mengurangi dan mengendalikan rasa stres yang dialami misalnya mengadakan program khusus lansia yang hipertensi secara rutin seperti senam lansia dan sebagainya serta membagikan leaflet tentang hipertensi agar pasien lebih mudah mengingatnya kembali informasi yang telah diberikan.

Bagi perawat diharapkan dapat membantu dalam memberikan informasi atau pendidikan kesehatan mengenai manajemen stres dan adaptasi koping yang bermanfaat sebagai bekal untuk mencegah kekambuhan hipertensi . Lansia perlu meningkatkan akses informasi mengenai riwayat hipertensi melalui manajemen stres dan adaptasi koping yang bermanfaat sebagai bekal untuk mencegah kekambuhan hipertensi misalnya melalui membaca buku ataupun giat 
melakukan konseling kepada petugas kesehatan sehingga diharapkan pasien dapat mengontrol stres secara penuh.

Perlu adanya penelitian lebih lanjut mengenai variabel yang berhubungan dengan faktor hipertensi lainnya misalnya pola makan, merokok, aspek genetik, aktivitas fisik, kepatuhan berobat dan sebagainya dengan populasi yang lebih besar atau bahkan multicenter. Hal ini diperlukan karena dilihat dari jumlah kasus hipertensi yang dialami lansia cukup besar .

\section{DAFTAR PUSTAKA}

1. Ariasti, Dinar, Thia Nur Pawitri. (2016). Hubungan antara Mekanisme Koping Terhadap Stres Dengan Kejadian Hipertensi Pada Warga di Desa Ngelom Sroyo Jaten Karanganyar. Jurnal Kosala Vol. 4 No. 1

2. Azizah, Lilik M. (2011). Keperawatan Lanjut Usia. Yogyakarta : Graha Ilmu

3. Nawangsari, Sisca Widhia \& Cemy Nur F. (2014). Hubungan Antara Mekanisme Koping Terhadap Stresor Dengan Kekambuhan Hipertensi Di Bagian Rawat Inap Puskesmas Kecamatan Gondangrejo Kabupaten Karanganyar . Jurnal Profesi Vol. 11 : 27-35

4. Andria, K.M. (2013). Hubungan Antara Perilaku Olahraga, Stress Dan Pola Makan Dengan Tingkat Hipertensi Pada Lanjut Usia Di Posyandu Lansia Kelurahan Gebang Putih Kecamatan Sukolilo Kota Surabaya. Jurnal Promkes, Vol. 1(2), 111-117.

5. Islami, Katerin Indah. (2015). Hubungan Antara Stres Dengan Hipertensi Pada Pasien Rawat Jalan Di Puskesmas Rapak Mahang Kabupaten Kutai Kartanegara Provinsi Kalimantan Timur
6. World Health Organitation. (2015). Global Health Observatory Data Repository. Diunduh 15 Febuari 2017, Diunduh 3 Mei 2018, http://apps. who.int/gho/data/view. main.60750? lang=en.

7. Madhumitha, Naraintran, Manohar. (2014). Influence of Stress and Sociodemographic Factors on Hypertension among Urban Adults in North Karnataka. Asian Journal of Biomedical and Pharmaceutical Sciences.;4(38):23-26.doi:10.15272/aj bps.v4i38.630.

8. Mirmohammadi, Taheri, Mehrparvar, Heydari, Saadati Kanafi, Mostaghaci M. (2014). Occupational Stress and Cardiovascular Risk Factors in HighRanking Government Officials and Office Workers. Iran Red Crescent Medical Jurnal. 2014;16(8):1-7. doi:10.5812/ircmj.11747.

9. Setiawan I Wayan A, Yunani, Kusyati E. (2014). Hubungan Frekuensi Senam Lansia Terhadap Tekanan Darah dan Nadi pada Lansia Hipertensi. Pros Konf Nas II PPNI Jawa Tengah. :229-236

10. Yonata, Ade \& Arif Satria.P.P. (2016). Hipertensi sebagai Faktor Pencetus Terjadinya Stroke. Jurnal Majority 5(3) :17-21

11. Kementrian Kesehatan RI. (2017). Analisis Lansia di Indonesia. Diunduh 3 Mei 2018, http://www.kemkes.go.id.

12. Riskesdas. (2013). Riset Kesehatan Dasar. Kementrian Kesehatan Republik Indonesia

13. Kementrian Kesehatan RI . (2013). Gambaran Kesehatan Lanjut Usia di Indonesia. Jakarta . Diunduh 3 Mei 2018,http://www.depkes.go.id/downlo ad.php?file $=$ download/pusdatin/bulleti n/buletin-lansia.pdf 
14. Afiah, Warditah., Sartiah Yusran \& La Ode M S. (2018). Faktor Risiko Antara Aktivitas Fisik, Obesitas Dan Stres Dengan Kejadian Penyakit Hipertensi Pada Umur 45-55 Tahun Di Wilayah Kerja Puskesmas Soropia Kabupaten Konawe. Jurnal Ilmiah Mahasiswa Kesehatan Masyarakat 3 (2) : $1-10$

15. Azizah, Rohmatul, Rita Dwi Hartanti. (2016). Hubungan Antara Tingkat Stress Dengan Kualitas Hidup Lansia Hipertensi Di Wilayah Kerja Puskesmas Wonopringgo Pekalongan. Issn 2407-9189 Univesity Research Coloquium

16. Frederickson, K. 2011. Callista Roy's adaptation model.Nurs. Sci.Q2011 24:301.DOI:10.1177/0894318411419 215

17. Islami, Katerin Indah. (2015). Hubungan Antara Stres Dengan Hipertensi Pada Pasien Rawat Jalan Di Puskesmas Rapak Mahang
Kabupaten Kutai Kartanegara Provinsi Kalimantan Timur

18. Notoatmodjo, Soekidjo. (2012). Metodologi Penelitian Kesehatan. Jakarta : Rineka Cipta

19. Mardiana, Yanih, Zelfino. (2014). Hubungan Antara Tingkat Stres Lansia Dan Kejadian Hipertensi Pada Lansia di RW 01 Kunciran Tangerang. Jurnal Forum Ilmiah, Volume 11 Nomor 2

20. Yuliani,Dwi Intan, Rizfika Amallia Ashary, Sigit Prasojo. (2013). Hubungan Tingkat Stres Dengan Mekanisme Koping Pada Lansia Yang Menderita Hipertensi Di Wilayah Kerja Puskesmas Wonopringgo Kabupaten Pekalongan

21. Rahmat. (2012). Hubungan Stres Psikososial dengan Mekanisme koping pada Lansia Hipertensi di Wilayah Posyandu Lanjut Usia Desa Trimurti Srandakan Bantul. 